\title{
Ischaemic heart disease and Cancer: competing malignant conditions
}

\author{
Alexandra C. Murphy ${ }^{1,2^{*}}$ (D, Anoop N. Koshy ${ }^{1,2}$ and Matias B. Yudi ${ }^{1,2}$
}

\begin{abstract}
Background: The growing population of cancer survivors and their high frequency of cardiovascular disease have resulted in a dramatic increase in cancer patients requiring cardiovascular intervention. However, there is a lack of evidence to guide optimal management in this complex population who have historically been excluded from cardiovascular trials.

Discussion: We review the recently published meta-analysis by Roule et al. The findings of this analysis demonstrate that patients with cancer presenting with acute coronary syndrome (ACS) have increased rates of inhospital cardiovascular mortality, bleeding and one-year cardiovascular mortality. All-cause mortality measured inhospital and at one-year were also significantly greater in cancer patients as was all-cause mortality in cancer patients that undergo percutaneous coronary intervention ( $\mathrm{PCl}$ ). In contrast to the short-term outcomes, rates of long-term cardiovascular mortality did not differ significantly between groups.
\end{abstract}

Summary: Patient-specific assessment of risk, accounting for disease characteristics and treatment, and close communication with oncology providers is vital in defining optimal treatment strategies in this population.

\section{Background}

Due to advancements in modern cancer therapy we are now seeing higher rates of cure and the conversion of a terminal illness into a chronic disease [1]. The growing population of cancer survivors and their high frequency of cardiovascular disease have resulted in a dramatic increase in cancer patients requiring cardiovascular intervention [2]. The causal relationship between acute coronary syndrome (ACS) and cancer can be partially attributed to the shared risk factor profile between the two disease states, such as obesity, diabetes and smoking [3]. Additionally, the pro-inflammatory and hypercoagulable state associated with many cancers and the acceleration of atherosclerosis caused by certain cancer therapeutics

\footnotetext{
* Correspondence: acmurphy@rocketmail.com

'Department of Cardiology, Austin Health, Austin Hospital, 145 Studley Road, Heidelberg, Melbourne, Victoria 3084, Australia

${ }^{2}$ Department of Medicine, The University of Melbourne, Melbourne, Victoria, Australia
}

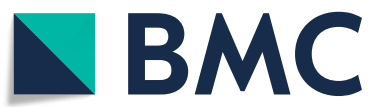

(c) The Author(s). 2020 Open Access This article is licensed under a Creative Commons Attribution 4.0 International License, which permits use, sharing, adaptation, distribution and reproduction in any medium or format, as long as you give appropriate credit to the original author(s) and the source, provide a link to the Creative Commons licence, and indicate if changes were made. The images or other third party material in this article are included in the article's Creative Commons licence, unless indicated otherwise in a credit line to the material. If material is not included in the article's Creative Commons licence and your intended use is not permitted by statutory regulation or exceeds the permitted use, you will need to obtain permission directly from the copyright holder. To view a copy of this licence, visit http://creativecommons.org/licenses/by/4.0/. The Creative Commons Public Domain Dedication waiver (http://creativecommons.org/publicdomain/zero/1.0/) applies to the data made available in this article, unless otherwise stated in a credit line to the data.

\section{MAINT text}

In their systematic review and meta-analysis, Roule et al. assessed the influence of cancer on early and late all-cause and cardiac mortality in the setting of ACS including ST-elevation myocardial infarction (STEMI) and/or percutaneous coronary intervention 
(PCI) [10]. This is an important contribution to the field, where there is limited evidence to guide practice. The findings of this analysis demonstrate that patients with cancer presenting with ACS have increased rates of in-hospital cardiac mortality, bleeding and one-year cardiac mortality. All-cause mortality measured in-hospital and at one-year were also significantly greater in cancer patients as was all-cause mortality in cancer patients that undergo PCI. In contrast to the short-term outcomes, rates of long-term cardiac mortality did not differ significantly between groups.

The results of this study highlight three important points. Firstly, of the patients examined, those with cancer were generally older, with a greater burden of co-morbidities which has important implications for ACS prognosis irrespective of malignancy status.

Secondly, cancer patients have higher rates of cardiac mortality, measured in-hospital and at one-year, than non-cancer patients. Of interest, cancer patients who underwent PCI had comparable cardiovascular mortality to non-cancer patients. Although not addressed in this study, it would be of interest to compare rates of invasive management in patients with and without cancer. Whether patients with cancer are less likely to receive invasive management due to a perceived higher risk of complications and if this may have contributed to the observed higher mortality warrants further study.

Thirdly, cancer patients represent a vastly heterogeneous population, and as such the synthesis of data in this field must be done carefully in order to maintain consistency. As cancer patients have been traditionally excluded from large-scale cardiovascular trials, high quality data is limited in this population. This further justifies the current publication as it provides a succinct summary of the available evidence, limited as it may be.

There are two major limitations to this study. First, the generalizability of some results is limited by the high degree of statistical heterogeneity between studies resulting from the clinical heterogeneity of the examined population and trial design. In particular, despite a statistically significant increase in all-cause mortality measured in-hospital and at one-year in cancer patients, there was high statistical variance between studies. Second, the lack of patient level data, including cancer type and the time interval between cancer diagnosis and ACS limits the interpretability of the findings. For example, the difference in survival is highly dependent on the cancer type, tumour stage, grade and biology [11]. Additionally, the treatment of the cancer itself may have indirect cardiac risk, such as increased bleeding propensity which has important prognostic implications [12].

\section{Conclusion}

With the vast improvement in cancer prognosis over recent decades, focus must be given to the optimal management of cardiovascular disease in the survivorship population. Patient-specific assessment of risk, accounting for disease characteristics and treatment, and close communication with oncology providers is vital in defining optimal treatment strategies in this population.

\section{Abbreviations}

ACS: Acute coronary syndrome; PCl: Percutaneous coronary intervention; STEMI: ST elevation myocardial infarction

\section{Acknowledgements}

Not applicable.

\section{Authors' contributions}

We confirm that all authors have participated in the work and agree with the content of the article. ACM and ANK performed a literature review. ACM wrote the initial draft of the article which was edited by ANK and MBY. The final manuscript was approved by MBY as the senior author.

\section{Funding}

Dr. Alexandra Murphy is supported by the Cardiac Society of Australia and New Zealand Research Scholarship. Dr. Anoop N Koshy is a recipient of the National Health and Medical Research Council of Australia/National Heart Foundation Post-Graduate Scholarship and Royal Australasian College of Physicians Blackburn Scholarship (1150874). The funders of these scholarships had no role in the production of this article.

Availability of data and materials

Not applicable.

Ethics approval and consent to participate Not applicable.

Consent for publication

Not applicable.

Competing interests

Dr. Anoop N. Koshy is an Associate Editor for BMC Cardiovascular Disorders.

Received: 2 March 2020 Accepted: 19 May 2020

Published online: 27 May 2020

References

1. Chang HM, Okwuosa TM, Scarabelli T, Moudgil R, Yeh ETH. Cardiovascular complications of Cancer therapy: best practices in diagnosis, prevention, and management: part 2. J Am Coll Cardiol. 2017;70(20):2552-65.

2. Kvakkestad KM, Wang Fagerland M, Eritsland J, Halvorsen S. Gender differences in all-cause, cardiovascular and cancer mortality during longterm follow-up after acute myocardial infarction; a prospective cohort study. BMC Cardiovasc Disord. 2017;17(1):75.

3. Malmborg M, Christiansen CB, Schmiegelow MD, Torp-Pedersen C, Gislason G, Schou M. Incidence of new onset cancer in patients with a myocardial infarction - a nationwide cohort study. BMC Cardiovasc Disord. 2018;18(1):198.

4. Darby SC, Ewertz M, McGale P, Bennet AM, Blom-Goldman U, Brønnum D, Correa C, Cutter D, Gagliardi G, Gigante B, et al. Risk of ischemic heart disease in women after radiotherapy for breast Cancer. N Engl J Med. 2013; 368(11):987-98

5. Armenian SH, Hudson MM, Chen MH, Colan SD, Lindenfeld L, Mills G, Siyahian A, Gelehrter S, Dang H, Hein W, et al. Rationale and design of the Children's oncology group (COG) study ALTE1621: a randomized, placebocontrolled trial to determine if low-dose carvedilol can prevent anthracycline-related left ventricular remodeling in childhood cancer survivors at high risk for developing heart failure. BMC Cardiovasc Disord. 2016;16(1):187. 
6. Berton G, Cordiano R, Cavuto F, Bagato F, Mahmoud HT, Pasquinucci M. Association between plasma lipid levels during acute coronary syndrome and long-term malignancy risk. The ABC-4* study on heart disease. BMC Cardiovasc Disord. 2019;19(1):119.

7. Guha A, Dey AK, Jneid H, Addison D. Acute coronary syndromes in Cancer patients. Eur Heart J. 2019;40(19):1487-90.

8. Hayek SS, Ganatra S, Lenneman C, Scherrer-Crosbie M, Leja M, Lenihan DJ, Yang E, Ryan TD, Liu J, Carver J, et al. Preparing the cardiovascular workforce to Care for Oncology Patients: JACC review topic of the week. J Am Coll Cardiol. 2019;73(17):2226-35.

9. Bonsu J, Charles L, Guha A, Awan F, Woyach J, Yildiz V, Wei L, Jneid H, Addison D. Representation of patients with cardiovascular disease in pivotal Cancer clinical trials. Circulation. 2019;139(22):2594-6.

10. Roule V, Verdier L, Blanchart K, Ardouin P, Lemaitre A, Bignon M, Sabatier R, Alexandre J, Beygui F. Systematic review and meta-analysis of the prognostic impact of cancer among patients with acute coronary syndrome and/or percutaneous coronary intervention. BMC Cardiovasc Disord. 2020;20(1):38

11. Saadatmand S, Bretveld R, Siesling S, Tilanus-Linthorst MM. Influence of tumour stage at breast cancer detection on survival in modern times: population based study in 173,797 patients. BMJ. 2015;351:h4901.

12. Holroyd EW, Mustafa AH, Khoo CW, Butler R, Fraser DG, Nolan J, Mamas MA. Major bleeding and adverse outcome following percutaneous coronary intervention. Interv Cardiol. 2015;10(1):22-5.

\section{Publisher's Note}

Springer Nature remains neutral with regard to jurisdictional claims in published maps and institutional affiliations.

Ready to submit your research? Choose BMC and benefit from:

- fast, convenient online submission

- thorough peer review by experienced researchers in your field

- rapid publication on acceptance

- support for research data, including large and complex data types

- gold Open Access which fosters wider collaboration and increased citations

- maximum visibility for your research: over $100 \mathrm{M}$ website views per year

At $\mathrm{BMC}$, research is always in progress.

Learn more biomedcentral.com/submissions 